\title{
オクタノール/アセトニトリル溶液中での複合アルコキシド法による チタン酸鉛微粒子の合成とその誘電特性
}

\author{
佐藤友章・棚瀬智和・今野幹男 \\ 東北大学工学研究科化学工学専攻, 980-8579 仙台市青葉区荒巻字青葉
}

\section{Synthesis and Ferroelectrical Properties of Lead Titanate Particles by Hydrolysis and Condensation of Complex Alkoxide in Octanol/Acetonitrile Solutions}

\author{
Tomoaki SATOH, Tomokazu TANASE and Mikio KONNO \\ Department of Chemical Engineering, Graduate School of Engineering, Tohoku University, \\ Aoba, Aramaki-aza, Aoba-ku, Sendai-shi 980-8579
}

\begin{abstract}
An attempt was made to produce lead titanate particles with a sol-gel process which adopted the hydrolysis and condensation reactions of complex alkoxide prepared from $\mathrm{Pb}\left(\mathrm{O}-i-\mathrm{C}_{3} \mathrm{H}_{7}\right)_{2}$ and $\mathrm{Ti}\left(\mathrm{OC}_{2} \mathrm{H}_{5}\right)_{4}$. The synthetic reactions of the complex alkoxide were carried out in octanol for $2-72 \mathrm{~h}$ at $70^{\circ} \mathrm{C}$, and the successive hydrolysis and condensation reactions were performed at water concentrations of $0.1-2.3 \mathrm{~mol} / \mathrm{dm}^{3} \mathrm{at}$ an ambient temperature in octanol-butanol solvents containing acetonitrile as a cosolvent. Size distributions of the lead titanate particles formed were measured with dynamic light-scattering. Selection of reaction conditions enabled the synthesis of spherical particles with average diameters less than $100 \mathrm{~nm}$ in ranges of water concentrations of $0.5-2.0 \mathrm{~mol} / \mathrm{dm}^{3}$ and acetonitrile concentrations of $15-20 \mathrm{vol} \%$ at a total monomer concentration of $0.05 \mathrm{~mol} / \mathrm{dm}^{3}$. The particles were subjected to heat treatment at various temperatures. The particles started to crystallize into a tetragonally perovskite structure at $200^{\circ} \mathrm{C}$, and transformed into a single phase at $750^{\circ} \mathrm{C}$. Dielectric constants of the particles heat-treated at $500-750^{\circ} \mathrm{C}$ were close to that of bulk, whereas the crystallite sizes in the particles were similar to the sizes of the particles produced in the reactions.

[Received May 31, 1998; Accepted July 13, 1998]
\end{abstract}

Key-words : Lead titanate, Spherical particle, Complex alkoxide, Hydrolysis, Condensation, Crystallite size, Dielectric constant

\section{1. 緒言}

強誘電体材料の電気的・機械的特性の向上の観点加ら，原料 粉体の微細化が求められており1) 3)，その製造法として金属 アルコキシド法が近年注目されている．従来の多元の金属アル コキシドを用いた反応法では，各金属アルコキシドの反応速度 の相違により，均一材料の合成が困難であったが，この欠点を 克服する方法として複合アルコキシド法が考案された4)。

複合アルコキシド法を用いた $\mathrm{Pb}\left(\mathrm{Zr}_{x} \mathrm{Ti}_{1-x}\right) \mathrm{O}_{3}$ 系微粒子の合 成研究もいくつか行われているが5) 10)，生成する粒子の形態 はさまざあで，それらの生成条件は必ずしも明確にされておら ず，得られた粒子径も $200 \mathrm{~nm}$ 以上であった，著者らもこの方 法を適用し，複合アルコキシド合成のための還流操作には主溶 媒としてエタノールを用い，更に生成した複合アルコキシドの 加水分解・縮合重合反応には共溶媒としてアセトニトリルを 添加することにより，粒径が90〜200 nm の単分散性 $\mathrm{Pb}\left(\mathrm{Zr}_{x}\right.$ $\left.\mathrm{Ti}_{1-x}\right) \mathrm{O}_{3}(\mathrm{PZT})$ 微粒子 $(x=0.2 \sim 0.8)$ を合成することができ た11). しかし， $x=0$ のときの強誘電性を示す $\mathrm{PbTiO}_{3}$ につい ては不定形の生成物となり, 球形微粒子は得られなかった。

金属アルコキシド法を用いた微粒子合成に抢いては，従来よ り溶媒の重要性が指摘されている. Ogihara らは，単元金属酸 化物（ $\left.\mathrm{TiO}_{2}, \mathrm{ZrO}_{2}, \mathrm{Al}_{2} \mathrm{O}_{3}, \mathrm{Ta}_{2} \mathrm{O}_{5}, \mathrm{Nb}_{2} \mathrm{O}_{5}\right)$ について，還流操作 では主溶媒としてオクタノールを，また，加水分解反応ではオ クタノールとブタノールの混合溶媒を使用し，その有効性を示 した ${ }^{12)}$. 更に, 溶媒上してのブタノールの重要性は, $\mathrm{SrTiO}_{3}$ を対象としたRiman らによっても示唆されている13)。 また， いずれの研究に抢いても加水分解反応に执いてアセトニトリル が添加されている。

そこで本研究では, 主溶媒の種類を変えて $\mathrm{PbTiO}_{3}$ 微粒子の
合成を試みた。更に従来の研究では微粒子の微細構造と誘電特 性との関係はほとんど調べられておらず，この点についての検 討も試みた。

\section{2. 実験方法}

\section{1 粒子の合成と生成粒子の粒径分布の測定}

金属アルコキシドとして，鉛ジイソプロポキシド（高純度化 学研究所製, $\left.\mathrm{Pb}\left(\mathrm{O}-i-\mathrm{C}_{3} \mathrm{H}_{7}\right)_{2}\right)$ とチタンテトラエトキシド（東 京化成工業製， $\left.\mathrm{Ti}\left(\mathrm{OC}_{2} \mathrm{H}_{5}\right)_{4}\right)$ をそのまむ用いた。使用した溶 媒はすべて和光純薬製特級試薬の $n$-オクタノール(純度 $99 \%)$ ，

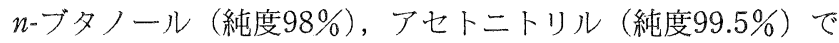
あり, 購入試薬をそのまま用いた。 オクタノールに $\mathrm{Pb}(\mathrm{O}-i$ $\left.\mathrm{C}_{3} \mathrm{H}_{7}\right)_{2}$ と $\mathrm{Ti}\left(\mathrm{OC}_{2} \mathrm{H}_{5}\right)_{4}$ をモル比 $1: 1$ の条件で, モノマ一総濃 度が0.014 0.14 mol $/ \mathrm{dm}^{3}$ の範囲上なるように溶解した後, 窒 素雲团気中 $70^{\circ} \mathrm{C}$ で $272 \mathrm{~h}$ 還流を行い, 金属アルコキシドの複 合化反応を行った．次に，この溶液に $10 \sim 60 \mathrm{vol} \%$ のアセト二 トリルを添加し, 体積が $0.14 \mathrm{dm}^{3}$ のアルコキシド溶液とした。 更に，これと同体積の50 vol\%オクタノールーブタノール溶液 と水の混合溶液をマグネチックスターラーでかくはんしながら 加えることで加水分解・縮合重合反応を行っだ. 反応はすべて $0.3 \mathrm{dm}^{3}$ のガラス製平底フラスコ中で行った. 加水分解・縮合 重合反応は室温で $3 \mathrm{~h}$ 以上行った。このとき外部からの水分を できるだ遮断するように注意して実験を行った．以下で述べ る溶媒と反応成分の濃度については，水一アルコール溶液を添 加した後の濃度を用いることにする。アセトニトリル濃度は 5〜30 vol\%, モノマー総濃度は0.005 0.1 mol $/ \mathrm{dm}^{3}$ で, 水濃 度は0.1 $2.3 \mathrm{~mol} / \mathrm{dm}^{3}$ の範聿に調製した。 反応終了後, 生成 粒子は遠心分離機（20000 rpm）で溶媒から分離し, エタノー 
ル溶媒中で $10 \min$ 超音波洗浄を数回繰り返した後, $150^{\circ} \mathrm{C}$, $10 \mathrm{~h}$ 乾燥し, 白色状の粉体として取り出した.

生成粒子の形態観察は透過型電子顕微鏡（TEM; 日立製作 所製，H-800）付属の走查型電子像観察装置（SEM ; 日立製 作所製，H-8010）により行った. SEM 観察には, 乾燥後の 粉体をカーボンテープにて試料台に固定し, 更に厚さ約数 $\mathrm{nm}$ のPt-Pd をスパッター法にて成膜したものを用いた。生成粒 子の粒径分布は, 反応終了後の溶液を注射器で $10^{-3} \mathrm{dm}^{3}$ 採取 し，エタノールで50倍に希釈した溶液を測定試料として，動 的光散乱法（大塚電子製, DLS-600) により求めた. 反応時 間を変えて生成粒子の平均径を測定したところ, $3 \mathrm{~h}$ 以上では 一定となることを確認したので, 加水分解・縮合重合反応は 3hでほぼ終了しているとした。

\section{2 生成物の熱処理と比誘電率の測定}

2.1節で得られた粉体の熱処理を大気中で $200 \sim 1000^{\circ} \mathrm{C}, 3 \mathrm{~h}$ の条件で行った. この試料に対し, X線発生装置（理学電機 製, ロータフレックス RU-200）及びグラファイトモノクロ メーター付属の広角ゴニオメーター（マック・サイエンス製, Model No. 3100R) t用い, 電圧 $40 \mathrm{kV}$, 電流 $30 \mathrm{~mA}$ の条件で, $\mathrm{CuK} \alpha$ 線により $2 \theta=20 \sim 60^{\circ}$ の範囲で X 線回折 (XRD) 測定 を行い, 結晶相の同定を行った。更に, 熱処理後の粉体の結晶 子の大きさをXRD データより求めた. X 線回折のピーク幅に は一般的に結晶子の大きさのほかに不均一ひずみによる影響も 含まれるので, Hall-Williamsonの解析法を用いて, $\mathrm{PbTiO}_{3}$ の回折ピーク $(100)\left(2 \theta \approx 22.8^{\circ}\right)$ とその同一方向の格子面であ る(200) $\left(2 \theta \approx 46.5^{\circ}\right)$ の積分幅をステップスキャン法により測 定して, 結晶子の大きさを算出した.

比誘電率測定用の試料として, 熱処理後の粉体を加圧成形器 を用いて直径が $13 \mathrm{~mm}$, 厚さが約 $0.4 \mathrm{~mm}$ のペレット状に成形 したものを用い, この試料の静電容量をキャパシタンスメー ター (エー・アンド・ディー製, $\mathrm{AD}-5822$, 印加電圧 $4.5 \mathrm{~V}$, 周波数 $800 \mathrm{~Hz}$ ) により測定した.ペレットは空気と粉体の混 合体となっているので, 以下のニーセルの式を用いて粉体の比 誘電率を算出した.

$$
1-\phi=\frac{\varepsilon_{1}-\varepsilon_{\text {all }}}{\varepsilon_{1}-\varepsilon_{2}}\left(\frac{\varepsilon_{2}}{\varepsilon_{\text {all }}}\right)^{1 / 3}
$$

ここで， $\phi$ は粉体の体積分率， $\varepsilon_{1}$ は粉体の比誘電率， $\varepsilon_{2}$ は空気 の比誘電率で $\varepsilon_{\text {all }}$ はペレット全体の比誘電率である. 粉体の体 積分率 $\phi$ は, 成形する粉体の重さ $W$, 密度 $\rho$, 形成後のペ レットの厚さ $D$ を測定し, 次式より算出した.

$$
\phi=\frac{(W / \rho)}{\pi r^{2} \times D}
$$

$r$ はペレット半径である。密度 $\rho$ は $10^{-2} \mathrm{dm}^{3}$ のピクノメー ターを用いて求めた。密度は, 熱処理温度が $200 \sim 950^{\circ} \mathrm{C}$ 範 囲では, $\rho=6.2 \sim 6.8 \times 10^{3} \mathrm{~kg} / \mathrm{m}^{3}$ であった。 また, 粉体の重 さは $W=0.46 \sim 0.62 \times 10^{-3} \mathrm{~kg}$ である.

\section{3. 実験結果ならびに考察}

\section{1 生成粒子の形態と粒径分布について}

はじめに, 本アルコキシド反応におけるモノマー総濃度につ いての検討を行った，還流温度 $70^{\circ} \mathrm{C} に$ 抢けるオクタノールに 対する鉛アルコキシドの溶解度を調べたところ, 約 $0.1 \mathrm{~mol} /$ $\mathrm{dm}^{3}$ であったので, 合成はこの濃度以下で行うことにした。 一方，合成においてモ)マー濃度を低くしすぎると（主として 次の条件で検討：モノマー総濃度 $=0.005 \sim 0.05 \mathrm{~mol} / \mathrm{dm}^{3}$, 水 濃度 $=1.5 \mathrm{~mol} / \mathrm{dm}^{3}$, アセトニトリル濃度 $=15 \sim 20 \mathrm{vol} \%$, 還 流時間は $2 \mathrm{~h})$, 粒子同士が凝集したような不定形のゲル状生成
物が得られたので，以下に述べる実験では， $0.05 \mathrm{~mol} / \mathrm{dm}^{3}$ の モノマー総濃度の条件で粒子合成を行った。

\subsection{1 アセトニトリル濃度の影響}

図 1 はアルコキシド溶液の還流時間を $2 \mathrm{~h}$, 水濃度を 1.5 $\mathrm{mol} / \mathrm{dm}^{3}$ として，アセトニトリル濃度を $15 \mathrm{vol} \%$ 及び $25 \mathrm{vol} \%$ としたときの生成粒子の SEM 画像と動的光散乱法により求め た粒径分布を示したものである。図 1 (a)を見ると，100 nm 以下の微粒子が多数見られるが，一部 $200 \mathrm{~nm}$ 以上の粒子も見 られた。このときの数平均粒径は $105 \mathrm{~nm}$ であり, 分散度は 35\%であった。一方，25 vol\%では，図 1 (b)に示すように， $100 \mathrm{~nm}$ 程度の粒子が多数見られるが，それらの凝集体と思わ れるものも観察される．そのときの粒径分布は $110 \mathrm{~nm}$ を中心 とする幅広い分布と530 nm を中心とした個数頻度の小さな分 布の二峰性の分布となっている.この530 nm 付近の分布は, SEM 写真で見られたような粒子の凝集体に対応しているもの と思われる。

アセトニトリル濃度が 5〜 10 vol\%の条件で行った実験では 粒子の凝集体が見られ，一方，25～30 vol\%の実験では粒子凝 集体のほかに200〜600 nm 大大粒子も生成していた。

以上の結果から，アセトニトリル濃度を $15 〜 20 \mathrm{vol} \%$ の範囲 としたときに，球形に近い形状の微粒子が合成されることが分 かった.

\section{1 .2 還流時間の影響}

アルコキシド溶液の還流の効果は, 分子的に組成の均一な複 合アルコキシドオリゴマーを生成し, 加水分解速度の均一化を 図ることにある。これまでの研究では還流時間を長くすると, 生成粒子の単分散性が高くなることが報告されている ${ }^{11)}$ 。 そ こで，本研究では還流時間を変えて生成粒子の粒径分布を測定 した.

これらの合成実験ではアセトニトリルを $15 \mathrm{vol} \%$ ，水濃度を $1.5 \mathrm{~mol} / \mathrm{dm}^{3}$ とし, 還流時間を $2 \sim 72 \mathrm{~h}$ の範囲で変化させた。 この結果, $24 \mathrm{~h}$ 以上では生成粒子径はほとんど変化しないこと が分かった。したがって，24hの睘流でアルコキシドの複合化 がほぼ完了しているものと思われる。図 2 は還流時間を $24 \mathrm{~h} と$ したときの生成粒子の SEM 画像とそのときの粒径分布を示し たものである.SEM 写真からは球形に近い粒子が生成してい ることが分かる。還流時間が $2 \mathrm{~h}$ のデータ（図 1 (a)）と比べ ると, $24 \mathrm{~h}$ の還流を行った場合, 粒径分布が全体的に小粒子側 に移動し, $70 \mathrm{~nm}$ 以下の個数頻度が増加している. 還流時間 が $24 \mathrm{~h}$ の数平均粒径は $88 \mathrm{~nm}$ であり, $2 \mathrm{~h}$ の場合と比べて約 17 $\mathrm{nm}$ 小さくなり, 分散度は約 $5 \%$ 低下し，30\%となった。この 理由としては, 複合化反応が十分進行していない場合, 未反応 のアルコキシドと複合化アルコキシドとの間に加水分解・縮合 重合反応速度に相違が生じるため不均一な粒子核生成となりや すく，粒子間の凝集頻度も増加するためであると思われる。

更に，20 vol\%アセトニトリルの場合についても還流時間の 影響を調べたところ, 平均径と分散度の変化については15 vol\%アセトニトリルの場合と類似の傾向が見られた。

\section{1 .3 水濃度の影響}

複合アルコキシドの加水分解反応と縮合重合反応は水濃度に 強く依存するため, 生成粒子の粒径分布は一般に水濃度に依存 する ${ }^{14) \sim 18)}$.

アルコキシド溶液の還流時間を $24 \mathrm{~h}$ ，アセトニトリルを 15 vol\%として, 水濃度を変えて合成した微粒子の平均粒径及び 分散度（二標準偏差/平均粒径）を図 3 に示す. 水濃度が $0.5 \sim$ $2.0 \mathrm{~mol} / \mathrm{dm}^{3}$ では生成粒子の平均粒径及び分散度に大きな変化 は見られなかった. 生成物のSEM 写真の観察より, 図 3 の水 

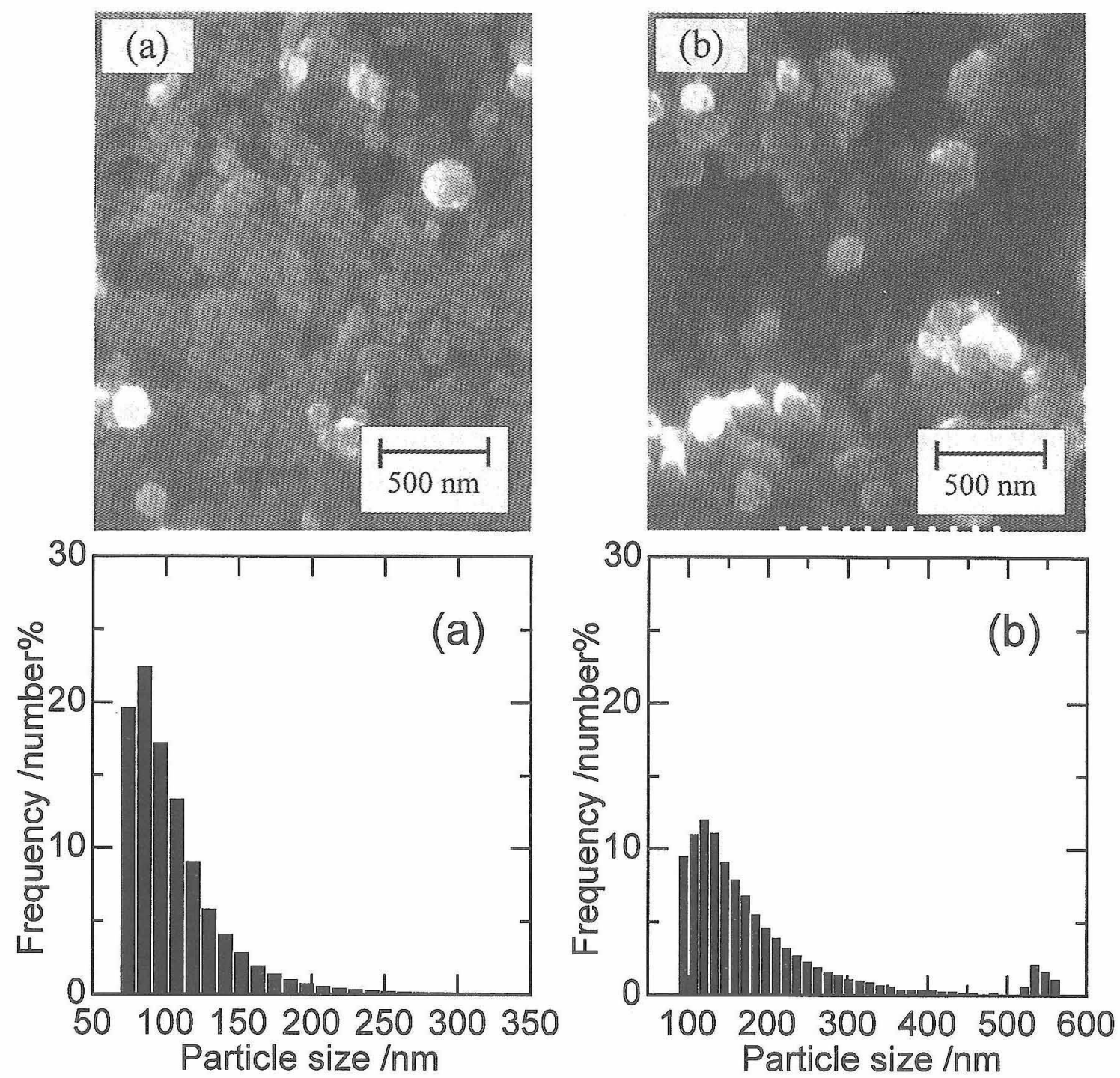

Fig. 1. SEM images and size distributions of particles prepared in reactions at acetonitrile concentrations of (a) 15 and (b) $25 \mathrm{vol} \%$, a total monomer concentration of $0.05 \mathrm{~mol} / \mathrm{dm}^{3}$ and a water concentration of $1.5 \mathrm{~mol} / \mathrm{dm}^{3}$. Synthetic reaction time of the complex alkoxide was $2 h$.

濃度範囲での生成粒子の形状と大きさは図 2 のものとほぼ同 じであった。

図 3 に示した水濃度範团外でも実験を行ってみた。水濃度 を低くし，0.1 0.3 mol $/ \mathrm{dm}^{3}$ とした実験では，生成物はゲル 状となり，粒径分布の測定を行うことはできなかった。一方， 水濃度を高くしすぎると，水は反応溶媒に不溶となっだ。そこ で，水濃度が高い場合については，均一相を形成する $2.3 \mathrm{~mol} /$ $\mathrm{dm}^{3}$ の水濃度の条件において実験を行った。しかしながら， この条件下に扝いては礙集粒子状の生成物となった。このこと は水濃度が高くなると反応終了時なで粒子間の凝集が進行する ことを示唆している。

\section{2 熱処理による結晶化挙動と誘電特性 \\ 3.2 .1 結晶化挙動}

図 4 は，水濃度を $1.5 \mathrm{~mol} / \mathrm{dm}^{3}$ 一定とし，還流時間を $2 \mathrm{~h}$ 及 び24h として合成した粒子を種々の温度で熱処理したときの XRDパターンである，乾燥後の粒子はいずれの還流時間でも 非晶質であった，還流時間が $2 \mathrm{~h}$ の場合は $250^{\circ} \mathrm{C} て ゙ ， 24 h$ の場

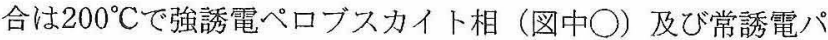
イロクロア相（図中×）が析出した。いすれれ還流時間で合成
した微粒子も熱処理温度の上昇とともにペロブスカイト相の占

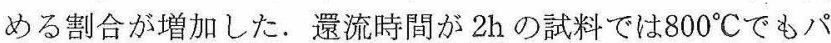

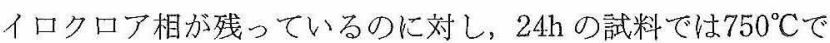
単相ペロブスカイトが得られた。

このように結晶化温度や単相ペロブスカイト相の出現温度が 低下した理由としては，長い還流操作により生成物組成の均一 化が進行したことが考えられる、いずれの還流時間でも500 以上の熱処理で得られた粒子の格子定数は $\mathrm{PbTiO}_{3}$ のバルク值 と同じでめった，更に，電子線プローブマイクロアナライザー 法（EPMA）によりそれら粒子の組成分析を行ったところ， $x=0.48 \sim 0.51\left(\mathrm{~Pb}_{x} \mathrm{Ti}_{1-x} \mathrm{O}_{3}\right)$ となり, アルコキシドの仕込み比 率とほぼ同じ組成の粒子が得られていることを確認した。

\section{2 .2 誘電特性}

図 5 は，アルコキシド溶液の罯流時間が $24 \mathrm{~h} ，$ アセニトリ 儿濃度が $15 \mathrm{vol} \%$ とし，水濃度が $1.5 \mathrm{~mol} / \mathrm{dm}^{3}$ として合成した 粒子を種々の温度で熱処理したときの比誘電率と結晶子の大き さの関係を示したものである，比誘電率は，熱処理温度ととも に徐々に增加し，ペロブスカイト単相となる $750^{\circ} \mathrm{C}$ 以上ではバ ルク值（80-140）と同程度になっている。なお，熱処理後の 


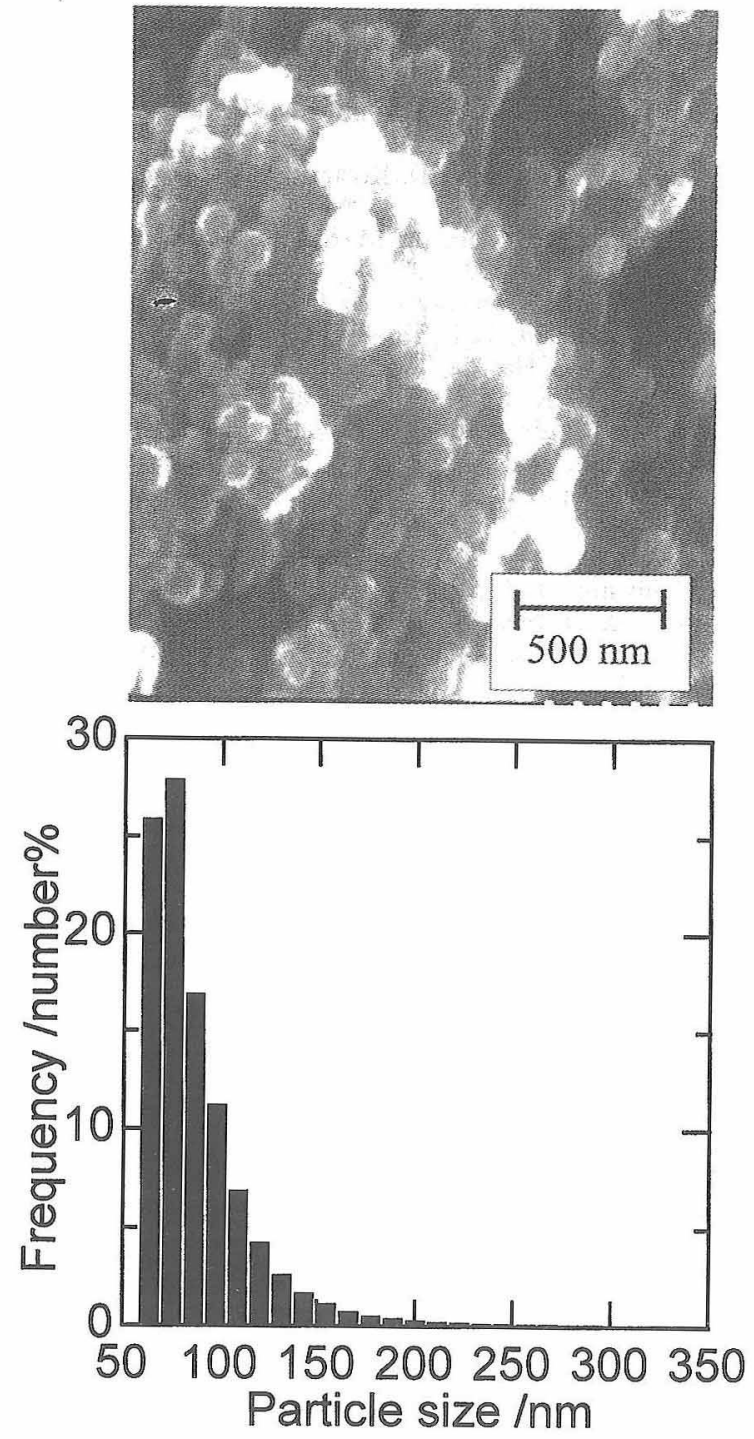

Fig. 2. SEM image and size distribution of particles prepared in reaction at an acetonitrile concentration of $15 \mathrm{vol} \%$. Synthetic reaction time of the complex alkoxide was $24 \mathrm{~h}$. Total monomer and water concentrations were the same as in Fig. 1.

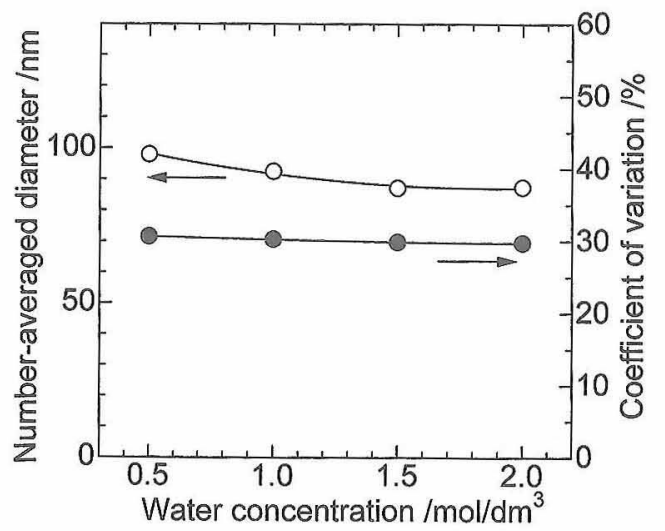

Fig. 3. Number-averaged diameter of particles and coefficient of variation of their size distribution versus water concentration in reactions at an acetonitrile concentration of $15 \mathrm{vol} \%$ and a total monomer concentration of $0.05 \mathrm{~mol} / \mathrm{dm}^{3}$. Synthetic reaction time of the complex alkoxide was $24 \mathrm{~h}$.
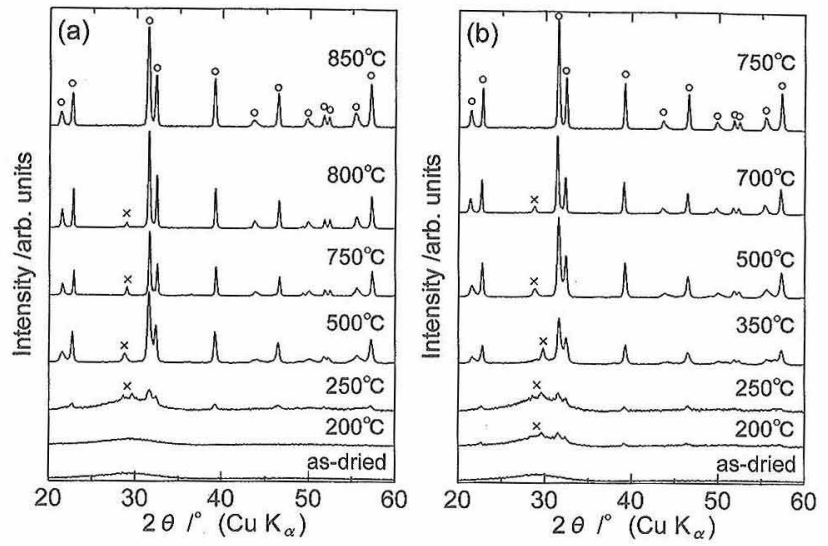

Fig. 4. XRD patterns of particles heat-treated at various temperatures for $3 \mathrm{~h}$. Synthetic reaction times of the complex alkoxide were (a) $2 \mathrm{~h}$ and (b) $24 \mathrm{~h}$. The other reaction conditions were given in Fig. 1(a); (O) perovskite and $(x)$ pyrochlore phase.

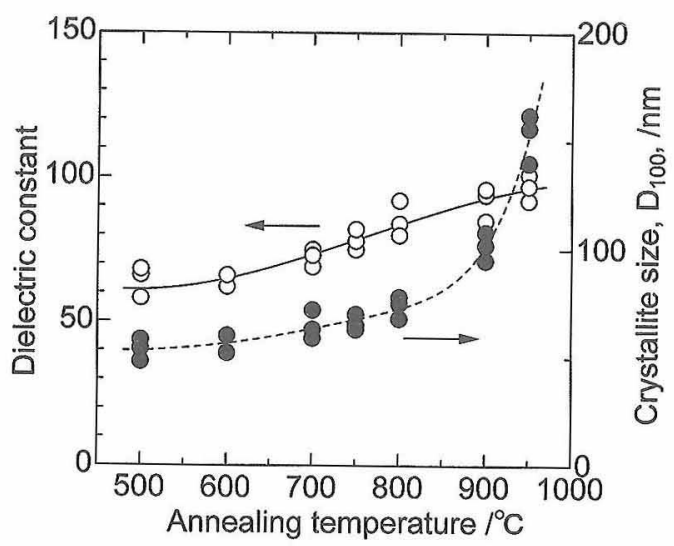

Fig. 5. Dielectric constants and crystallite sizes, $D_{100}$, of $\mathrm{PbTiO}_{3}$ particles heat-treated at $500-950^{\circ} \mathrm{C}$ for $3 \mathrm{~h}$. The particles were prepared from the complex alkoxide reacted for $24 \mathrm{~h}$. The other reaction conditions were the same as in Fig. 1(a).

粉体のSEM 観察を行った結果, 微粒子は $500 \sim 600^{\circ} \mathrm{C}$ で焼結 が始まっていることを確認した。 図 5 を見ると, 結晶子の大 きさは, 熱処理温度が $800^{\circ} \mathrm{C}$ ま゙徐々に, それ以上の温度で は急激に増加している。熱処理温度が $750^{\circ} \mathrm{C}$ 以下での誘電率の 增加は, ペロブスカイト相の体積分率が増加し，その分常誘電 パイロクロア相の割合が減少していることと, 結晶子の成長に よるものと思われる。一方, $800^{\circ} \mathrm{C}$ 以上ではペロブスカイト単 相となっているので, 誘電率の変化は結晶子の成長によるもの と考えられる.

ペロブスカイト単相が得られる温度 $\left(750^{\circ} \mathrm{C}\right)$ で熱処理した 粉体の結晶子の大きさは, 60-70 nm であり, 生成粒子径とほ ぼ同程度で岁った。このことは, 生成粒子径によって結晶子の 成長が抑制されている可能性を示唆しているものと思われる。 更に, 従来の固相法で合成される仮焼粉体の結晶子の大きさに 比べて $1 / 10$ 程度小さく，一方，比誘電率はバルクに匹敵する 值を示すことが分かった。

\section{4. 結 論}

オクタノールとアセトニトリルの混合溶媒中での金属アルコ キシドの加水分解によりチタン酸鉛微粒子の合成を試み，以下 の知見を得た。 
（1）アセトニトリル濃度が15２0 vol\%，水濃度が0.5〜 $2.0 \mathrm{~mol} / \mathrm{dm}^{3}$ の範囲で平均粒径が $100 \mathrm{~nm}$ 以下の球形微粒子を 合成することができた。

（2）熱処理した粉体の結晶子の大きさは生成粒子径と同程 度に小さく, 一方, 比誘電率はバルクに近い值を示すことが分 かった.

謝辞 本研究を遂行するに当たり, 誘電率測定に関し有益 な助言, コメントを頂いた東北大学工学研究科応用物理学専攻の 小野泰弘助手, 及び誘電率測定装置を製作して頂いた東北大学化 学・バイオ系機械工場の加味賢一技官に深く感謝致します。

\section{文 献}

1) Y. Ozaki, Nippon no Kagaku to Gijutsu, 25, 43-51 (1984).

2) H. Ikawa, Seramikkusu, 27, 701-06 (1992).

3) S. K. Mishra and D. Pandy, J. Phys. Condens. Matter, 7, 9287-303 (1995).

4) K. Kakegawa, J. Mohri, K. Imai, S. Shirasaki and K. Takahashi, Nippon Kagaku Kaishi, 4, 692-95 (1985).

5) T. Ogihara, H. Kaneko and N. Mizutani, J. Mater. Sci. Lett., 7, 867-69 (1988).

6) T. Kasai, Y. Ozaki and D. Shiga, Seramikkusu Ronbunshi, 96 140-45 (1988).

7) K. Kezuka, Y.Hayashi and T. Yamaguchi, J. Am. Ceram.
Soc., 72, 1660-63 (1989).

8) H. Hirashima, E. Onishi and M. Nakagawa, J. Non-Cryst. Solids, 121, 404-06 (1990).

9) T. Fukui, C. Sakurai and M. Okuyama, J. Mater. Res., 7, 79194 (1992).

10) B. Maric, M. Kosec and D. Kolar, Inf. MIDEM, 25, 98-107 (1995).

11) T. Satoh, Y. Yamamoto and M. Konno, Kagaku Kogaku Ronbunshu, 23, 998-1000 (1997)

12) T. Ogihara, T. Yanagawa, N. Ogata and K. Yoshida, $J$. Ceram. Soc. Japan, 101, 315-20 (1993).

13) A. B. Hardy, G. Gowda, T. J. Mcmahon, R. E. Riman, W. E. Rhine and H. K. Bowen, "Preparation of Oxide Powders," Ultrastructure Proceeding of Advanced Ceramics, Ed. by J. D. Mackenzie and D. L. Ulrich, Wiley Interscience, New York (1987) pp. 407-28.

14) W. Stöber, A. Fink and E. Bohn, J. Collid. Interf. Sci., 26, 6269 (1968)

15) K. Uchiyama, T. Ogihara, T. Ikemoto, N. Mizutani and M. Kato, J. Mater. Sci., 22, 4343-47 (1987).

16) G. H. Bogush, M. A. Tracy and C. F. Zukoski, IV, J. NonCryst. Solids, 104, 95-106 (1988).

17) L. Lerot, F. Legrand and P. de Bruycker, J. Mater. Sci., 26, 2353-58 (1991).

18) T. Satoh, M. Akitaya, M. Konno and S. Saito, J. Chem. Eng. Japan, 30, 759-62 (1997). 